\title{
《黄帝内经》成书的西汉文化背景
}

\author{
陕西中医学院，陕西 咸阳 ${ }^{1}$
}

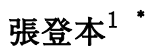

\section{Cultural Background of the Western Han Dynasty of Huangdi Neijing}

\begin{abstract}
Zhang Dengben ${ }^{1}$ *
${ }^{1}$ Shaanxi University of Traditional Chinese Medicine, Xianyang, Shaanxi 712046

Huangdi Neijing was completed during the several decades after Shijiand before Qilue, whose main content draws from the medical achievements of Qin and Han Dynasty, and is deeply influenced by Confucianism, Buddhism and Daoism of Qin and Han Dynasty. What creates the profound impact on its construction of medical theories are the thoughts of this period, such as "Valuing life", "people", "Valuing Yang", "Valuing earth", "the Heaven theory", "the Unity of Man and Nature", and the important works of this period, such as Huai Nan Zi, Chun Qiu Fan Lu, Shiji. Even the astronomy, calendar and medical achievements of this period are the basic material absorbed into the theories of Huangdi Neijing.
\end{abstract}

Key Words : Huangdi Neijing; Completion of the book; Culture of the Western Han Dynasty

《黄帝内经》的成书时代有黄帝时代说，有战国时 代说，有秦汉时代说，有西汉说，有两汉说，等等。近 20 年来更有成书于西汉中晚期说，确切地说应当是在 《史记》问世（公元前91年）以后至公元前6年刘向 《别录》完稿的近百年期间应当是《内经》的成书时 期。而此前近两个世纪西汉帝国的政治、经济、文化、 科技（尤其是医药科技）的发展为《黄帝内经》的成书 创造了良好的相爷有利条件。因为任何重大事情的发生 都不是偶然的，都有其相爸的特定背景，更何况爷乎到

* 교신저자 : 中國 (712046) 陕西省 西安市 西咸新区世纪大道 陝西中医学院 內經敎研室

E-mail : zdben69@163.com Tel : 029-38185000 접수일(2013년 9월13일), 수정일(2013년 10월29일), 게재확정일(2013년 11월15일).
中国人健康事业的《黄帝内经》成书这一重大事件的出 现也不例外。

\section{一、社会背景}

就《黄帝内经》成熟的社会背景而言，是西汉王朝 在刚刚结束了春秋战国时期的奴隶制不久，封建大一统 的中央集权制度刚刚建立，西汉初期的统治者需要巩固 这一成果，但是经历了几千年的奴隶制度的残余势力和 残余思想不可能在短期内消失殆尽，这些思想和实力还 深深的影响着西汉初期的统治阶层, 这也就是这一时期 所奉行的“郡国制”的背景。封国制和郡县制并存的政治 背景和思想背景在《黄帝内经》理论构建中是有充分体 现的。如《灵枢. 师传》之“入国问俗”则反映了当时封 
国制的社会背景， 《素问·灵兰秘典论》则充分体现了 当时的统治阶层极力推行封建大一统中央集权制度的强 烈意识。

西汉, 又称前汉, 是中国古代的一个朝代, 与东汉 合称汉朝, 是中国第一个强盛稳固的朝代。公元前 206 年汉高租刘邦自称汉王, 公元前202年, 刘邦称帝, 建 国号汉。这年的五月定都长安, 西汉王朝诞生。公元8 年王莽称帝, 改国号为新, 西汉灭亡, 西汉王朝共经历 了210年。汉高租称帝之后，有鉴于秦亡经验，透在政 策上采取了道家“黄老之术”“无为而治” 的理念, 又经过 文、景、武帝的励精图治、奋力经营。奉行了于民休养 生息的“重民”治国方略, 兴修水利, 减免赋税, 发展生 产，使农业、手工业、商业、人文艺术以及自然科学都 得到了长足的发展。随着科学技术的提高, 使得以治 金、纺织为主的西汉手工业的生产效率大大提高。加之 采用了和亲匈奴的外交政策, 维持了边疆的和本。这一 系列政策的实施, 大体维持和葍定了西汉帝国相对稳 固、强大、繁荣、富有的业基。同时进一步也加强了中 央集权统治。因此西汉早中期约一百五十年左右的时 间，国家是强大的、是统一的，政治上基本是稳定的。

《黄帝内经》的成书大约在公元前 91 年至公元前 6 年 之间的近百年期间, 虽然这一时间是西汉王朝逐渐由强 盛走向衰落阶段, 但是在“武帝盛世”以后又有“昭宣中 兴”, 由于继续奉行武帝晚年休息民力、重视生产的政 策, 政治局面重新稳定, 国力得到恢复, 成为西汉盛世 的继续, 延续了文、景、武三帝所创造的西汉盛世，这 也为《黄帝内经》的成书提供了良好的社会背景。

盛世修书是一条亘古不变的规律。在这种政治背景 之下孕育并产生了像《淮南子》《春秋繁露》《史记》 等文化巨著, 同样也为《黄帝内经》这部以生命科学为 主体的百科全书的发生, 提供了充沛的养分和丰厚的沃 土。

\section{二、文化背景}

稳定的政治经济环境必然促进繁荣的文化发展。医 药学科也是一种文化。“文是基础医是楼”, 以《黄帝内 经》为主所椷定的医药学科是建立在中华民族传统文化 根基之上的自然科学。因此, 西汉时期的繁荣文化是 《黄帝内经》成书必不可少的沃土和养分, 为其理论的
构建创造了十分有利的文化背景。

$(-)$ 西汉对先秦诸子思想的梳理研究, 促进了《黄帝 内经》理论的构建和成书

西汉时期对先秦诸子百家的思想进行了系统、深刻 地整理和研究。其中最具影响力的杂家的代表著作《淮 南子》全面继承了先秦诸子的学术思想, 融诸子百家学 术思想于一炉, 而在以医言政、以医议事的理念之下, 全面地将生命科学的相爸内容渗透于对诸子思想的阐 释, 这就为《黄帝内经》理论的构建产生了十分重要的 借鉴和示范作用。

司马谈的《论六家要旨》是西汉时期研究和梳理先 秦诸子思想的的代表作, 将先秦诸子思想按其学术体系 概括为阴阳、儒、墨、名、法、道六家，并加以论述， 第一次分析出自春秋战国以来重要的学术流派。也反映 出汉武帝时期以儒家思想为主，萧用阴阳家、法家和道 家“黄老”的学说, 即所谓“汉家自有制度, 本以霸王道 杂之”, 而并不 “纯任德教”(《汉书·元帝纪》)的思想。 从而反映了汉武帝时期复杂的社会和统治思想状况。其 六家之说, 不仅为后来司马迁给先秦诸子作传具有重要 的启示和借鉴，也为西汉末期名儒刘向、刘歆父子给先 秦诸子十家的分类奠定了基础。

先秦阴阳、儒、墨、名、法、道等各流派的学术思 想对《黄帝内经》理论的构建都有十分深刻的影响, 这 在《黄帝内经》的字里行间中俯拾皆是。在这十家学术 流派之中，对中国传统文化影响最大的莫过于儒、墨、 道、法四大学派。《黄帝内经》在其理论构建过程中, 除了受到精气、阴阳、五行、神论等哲学思想十分深刻 的影响之外, “诸子百家”的学术思想很自然地浸润并渗 透于其中，糅杂于其间，用以解释相爸的生命现象，解 决相爸的医学问题, 构建医学体系 [1]。各家的学术思 想虽然自成其家，但却相互渗透，互相交叉，并不排 斥。这种文化现象恰恰为《黄帝内经》构建自己的理论 所利用。

$(二)$ 西汉重视黄老之学对《黄帝内经》成书的影响

“黄老”是指老子和黄帝。《论衡·自然》中有十分明 确的界定, 认为“贤之纯者, 黄、老是也。黄者, 黄帝 也; 老者, 老子也”。司马谈的《论六家要旨》所概括 的“因阴阳之大顺, 采儒墨之善, 撮名法之要”新道家的 学术特征, 就是黄老之学的学术特征。具体言之, 就是 
“道法结合, 萧采百家”的学术特征。其中道家思想是其 哲学基础, 法家的观点是其基本的政治主张, 兼采百家 思想则是其政治主张的辅翼。可以说是吸收了众家之 长, 使各家之学在新的理论体系中形成了拾遗补缺和优 势互补的效果, 所以才能够产生“压倒百家” 的显赫效 果, 成为西汉前期真正的 “显学”。“黄老之学” 的学术取 向, 既适应了当时为巩固中央集权迫切的政治需要, 也 符合了学术思想发展的内在逻辑需求。这一时期的“黄 老之学”大倡法治, 适应了西汉巩固政权、富国强兵的 时代主旋律 ; 其集众家之长, 则是百家之学经过充分的 争鸣之后的必然归宿，同时也是西汉王朝在政治上的统 一局面在学术思想中的反映和必然要求。这样的学术思 想能够被汉高祖、窦太后，乃至文帝、景帝重视盛极一 时并最终压倒百家，自然是情理之中的事情。

《黄帝内经》之所以在西汉时期成书, 不能不与昌 盛于西汉早中期的“黄老之学” 有着十分密切的爷系。 “黄老之学”对其理论构建和成书的影响, 不仅仅是将医 药学著作之所以托名 “黄帝” 的意识形态背景和文化背 景。正如《淮南子·修务训》之“世俗之人, 多尊古而 贱今, 故为道者必托之于神农、黄而后能入说”之论, 也有“黄老之学”所倡导的“道论”“无为而治”等等理念直 接影响着《黄帝内经》理论的发生。仅仅就“道论”而 言, 《黄帝内经》将“道”这一范畴引入医学领域之后, 全面广泛地用来表达宇宙万物、生命活动规律和相爸的 理论原则, 在269次“道”的应用中, 几乎将当时人们所 能认识到的与生命科学相爸的所有理论原则和相爸规律 都纳入到“道”的范畴。.将“道法自然”“无为而治”的理 念全面引入并构建养生理论 [2]。

(三)西汉“民本”思想对《黄帝内经》理论建构的影响

自汉朝开国至武帝初年, 由其是汉文帝、汉景帝, 由于连续实行减轻人民的负担, 减轻刑罚, 恢复生产和 休息民力的“民本”政策，国家已拥有相当充足的经济实 力。加之这近百年期间, 国家无事, 也无严重的自然灾 害, 所以出现了历史上少有的国家稳定发展, 国力大大 增强, 民富国强的太平盛世。在这样的社会背景之下, 与“民本”国策联系紧密的医学学科自然也会受到朝野的 重视而得到相应的发展, 这也就是能凸显文景时期文化 和思想特征的重要文献《淮南子》, 以及通汉武帝时期 的《春秋繁露》中大量的医药学知识和丰富的养生知
识, 表达这一时期的医药学成就的理由。《黄帝内经》 之所以能在这一时期成书，不能不与这一时期休息民力 的“民本”政策有着十分紧密的爸系。而且“民本”思想在 《内经》原文中也有体现，如“黄帝问于岐伯日：余子 万民，养百姓，而收其租税。余哀其不给，而属有疾 病。余欲勿使被毒药, 无用砣石, 欲以微针通其经脉, 调其血气，营其逆顺出入之会。令可传于后世，必明为 之法。令终而不灭, 久而不绝, 易用难忘, 为之经纪。 异其章, 别其表里, 为之终始。令各有形, 先立《针 经》。愿闻其情” (《灵枢·九针十二原》) , 这可以说 是《内经》中“民本”思想的集中体现。

(四)“重生”理念对《黄帝内经》理论建构的影响

一部《黄帝内经》全部内容的主旨就是在“重生”的 理念之下形成的, “天覆地载, 万物悉备, 莫贵于人” （《素问·宝命全形论》) 则是对这一主旨的明确表 达。“宝命全形”不仅道出其成书的目的和构建其理论的 意义，同时也反映其成书的“重生”文化背景。“重生”应 当是全人类的共同理念，也是中国历代统治阶层的治国 方略，自从有文字记载到《黄帝内经》的成书，这一思 想一致连绵不绝。因为“民惟邦本，本固邦宁” (《尚 书·五子之歌》），民众是国家的基石，只有国家的基 石牢固，国家才能安宁。这就是历代统治阶层重视“民 本”的执政治国思想基础。《庄子·养生主》强调于民休 养生息, 《兵法·月战》的“天地之间，莫贵于人”之 说, 《吕氏春秋》开卷首论“重生”, 《春秋繁露》于 《循天之道》中专论养生等等, 无一不是“重生”这一古 今中外全人类共同理念的体现，《黄帝内经》正是在这 一人类共同理念的文化背景下构建其理论及其成书的, 所传载全部医学和语义学有爸的知识, 无一不是“重生” 理念的体现。

(五)西汉时期“天论”观点对《黄帝内经》理论构建的 影响

何谓“天”? “所谓天者, 纯粹朴素, 质直皓白, 未始 有与杂糅者也” (《淮南子·原道训》) 就给“天”这个范 畴以明确的、唯物的，“自然之外别无天”的内涵界定。 如若用今天的语言予以表达, 所谓“天”就是指一切事物 客观存在的固有规律，当然也包括自然界、包括与地相 对的“天空”等等。《黄帝内经》理论中大凡涉及“天”的 相爸论述，无一例外的秉承了这一旨意，如仅仅就其中 
涉及“天”的篇名而言，如《素问》的《上古天真论》 《生气通天论》 《天元纪大论》, 《灵枢经》的《天 年》《通天》等无不如此。在588次涉“天”之论中除了 延伸到生命科学领域而被赋予特定的医学内涵之外, 别 无其他内涵。

(六)西汉时期“重土”思想对《黄帝内经》理论构建的 影响

西汉时期“重土”的思想与其所处西汉崇尚“黄老之 学”有着十分密切的䏌系。五帝中的“黄帝” 以土为德, 故在当时文化界的著书立说多托名于黄帝。董仲舒更是 这一西汉帝国的主旨思想的极力倡导者, 在他的著作中 力主以土为重的理念就不足为奇了。如“土者火之子 也, 五行莫贵于土……者, 五行最贵者也” (《五行 对》) 。 《黄帝内经》充分接受了这一思想并且用于解 决医学中的实际问题。如“脾者, 土也, 治中央, 常以 四时长四藏, 各十八日寄治, 不得独主於时也。脾藏者 常著胃土之精也, 土者生万物而法天地, 故上下至头 足，不得主时也” (《素问·太阴阳明论》)。再如“本 人之常气禀於胃, 胃者平人之常气也, 人无胃气日逆, 逆者死……人以水为本, 故人绝水则死, 脉无胃气亦 死” (《素问·本人气象论》)。“脾脉者土也, 孤藏以 灌四傍者也……五藏者, 皆禀气於胃, 胃者, 五藏之本 也, 藏气者, 不能自致於手太阴, 必因於胃气, 乃至於 手太阴也, 故五藏各以其时, 自为而至於手太阴也” （《素问·玉机真脏论》）。这一在“重土”思想影响下 构建的人体以脾胃为本观点在中医学的理论体系中, 无 论是脏腑气血的生理还是病理, 无论是临床诊断还是对 疾病的治疗, 都具有十分重要的学术地位, 李杲所创立 的脾胃学派无疑是《繁露》“重土”思想的重要影响以及 是脾“胃者, 五藏之本”观点的延伸。

(七)西汉 “重阳”思想对《黄帝内经》的理论建构和成 书影响

《繁露》在论述阴阳爸系时强调“阳尊阴卑”, 这种 重“阳”的思想是全书的主旨, 并以此论述夫妻爸系, 认 为“丈夫虽贱皆为阳，夫人虽贵皆为阴” ( 《阳尊阴 卑》）；论述君臣兊系，认为“当阳者，君、父也”，以 及论述天地万物的爸系, 进而得出“阴者, 阳之助也” “阳贵而阴贱，天之制也” (《天辨在人》) 的结论。 《内经》及其缔造的医学体系秉承了这一时期“阳为主
阴为从”的重“阳”理念, 并将其运用于医学体系之中, 虽然有“生之本，本于阴阳”“阴平阳秘，精神乃治，阴 阳离绝，精气乃竭”，阴阳是“寿命之本”的认识，但是 在这一时期“重阳”思想的影响下，认为其中的阳气是最 为重要的，阳气在阴阳爸系中居于主导地位，故有“阳 气者，精则养神，柔则养筋”。“阳气者，若天与日，失 其所则折寿而不彰”之论（《素问·生气通天论》），明 确地指出了阳气是生命活动的动力, 在生命过程中具有 十分重要的作用。阳气所具有的温煦机体组织, 抗御外 邪侵袭，主持气化开合，维系阴阳平衡等多方面的重要 功能, 对于生命活动十指爸重要的, 因此有“凡阴阳之 要, 阳密乃固”“阳强不能密，阴气乃绝”之论述，并以 太阳与天地万物的爸系为喻, 用 “薄厥” “煎厥”疔疮等常 见病症为例, 凸显人体阳气在生命活动中的主导作用, 这一“重阳”思想也成为后世医家重视阳气理论的源头, 更其是明代“温补学派”创立的依据。

(公)西汉时期 “天人相应” 观对《黄帝内经》的理论构 建和成书影响

天人相应的整体观是《黄帝内经》构建的医学理论 的基本特点之一, 体现在这一医学知识体系的各个层 面。在西汉时期的思想界都十分重视“天人相应”的整体 观念, 无论是刘安还是董仲舒都是如此, 如《淮南子》 是在肯定天的客观性基础上，明确提出了“人与天地相 参” “人事与天地相参” 的天人相应论点。认为人与天 地万物皆禀一气而生, 在天人同气思想的指导下, 创建 了天人同构理论。认为“阴阳同气相动”, 故“天之与人 有以相通”, 实际上就是天人感应的思想。强调了天人 相应的整体联系的观念, 如“天地宇宙，一人之身也; 六合之内，一人之制也”“孔空肢体皆通于天。天有九 重, 人亦有九䛎” (《本经训》)。指出人类生活在宇 宙之间，和自然界万事万物是息息相通的。《春秋繁 露》也认为 “人有三百六十节, 偶天之数也; 形体骨 肉，偶地之厚也; 上有耳目聪明，日月之象也; 体有空 空理脉, 川谷之象也; 心有爱乐喜怒, 神气之类也。此 见人之绝于物而参天地。是故人之身，首妢而员，缘天 容也; 法, 象星辰也; 耳目戻戻, 象日月也; 口鼻呼 吸, 象风气也; 胸中达知, 象神明也; 腹饱实虚, 象百 物也” (《人副天数》)。如果考察《黄帝内经》之“天 为阳, 地为阴, 日为阳, 月为阴, 大小月三百六十日成 
一岁，人亦应之”（《素问·阴阳离合论》）。“天气通 于肺, 地气通于嗌, 风气通于肝, 雷气通于心, 谷气通 于脾, 雨气通于肾。六经为川, 肠胃为海, 九空为水注 之气。以天地为之阴阳, 阳之汗, 以天地之雨名之; 阳 之气, 以天地之疾风名之。暴气象雷, 逆气象阳。故治 不法天之纪，不用地之理，则灾害至矣”（《素问·阴 阳应象大论》)。《灵枢. 岁露论》的“人与天地相参 也，与日月相应也”, 以及《素问》的《六节藏象论》 《生气通天论》之“天地之间，六合之内……九控、五 藏、十二节皆通乎天气” 的有爸内容之后就会发现, 两 者的精神基本一致。

\section{三、科学文化发展的影响}

华夏文化的发展, 历史悠久, 源远流长。根据现存 古文献之追述或世代传说及出土之文物, 说明早在上古 时期, 劳动人民便逐步由结绳记事而过渡至以文字记 事。故有“上古结绳而治, 后世圣人易之以书契。百官 以治，万民以察，盖取诸央”之论（《易·系辞传》）。

\section{(一)文、历法}

在天文、历法方面，早在殷商时期的甲骨卜辞中， 即有诸多此类记载。在先秦两汉文献中, 不仅有天文、 历法方面的专论，如《史记》历书有天官书、《汉书》 律历志与天文志等; 而且有天文、历法方面的专著。如 《汉书·艺文志》著录有天文类二十一家, 四百四十五 卷; 历谱类十八家, 六百零六卷。说明该时期对天文、 历法的发展, 虽带有某些占星术及术数方面的唯心思 想, 但对天文与历法的研究, 已达相当水本。现就其与 医学有爸的内容整理如下:

\section{1. 天体结构}

中国古代天文学家对天体结构有盖天说、浑天说和 宣夜说三种认识。

(1)盖天说。《黄帝内经》借用了盖天说这一宇宙的 模型构建自己的相爸医学理论, 认为“人之肢节, 以应 天地……天圆地方, 人头圆足方以应之”（《灵枢·邪 客》), 用以体现医学理论中“天人相应”观念的相爷知 识。还应用 “天不足西北, 故西北方阴也, 而人右耳目 不如左明也; 地不满东南, 故东南方阳也, 而人左手足 不如右强也” (《素问·阴阳应象大论》) “东南方, 阳
也，阳者其精降于下，故右热而左温。西北方，阴也， 阴者其精奉于上, 故左寒而右凉。是以地有高下, 气有 温凉, 高者气寒, 下者气热, 故适寒凉者胀, 之温热者 疮, 下之则胀已, 汗之则疮已, 此凑理开闭之常, 太少 之异耳……阴精所奉其人寿, 阳精所降其人夭”（《素 问·五常政大论》) 的盖天说的宇宙模型，阐述人类的 寿夭与地域爸系，用以解释人类的健康状况以及寿命的 长短与这一宇宙结构之下的地域环境、气候变化的兊 系。何谓盖天说? 之一学说认为天是圆形的, 像一把张 开的大伞覆盖在地上，地是方形的，像一个棋盘，日月 星辰则像爬虫一样过往天空, 因此这一学说又被称为 “天圆地方说”，可能起源于殷末周初。先秦时期有所发 展, 西汉时期趋于明确, 故在《淮南子.天文训》中有 “天圆地方，道在中央”以及 “天不足西北，地不满东南” 之说, 故有理由认为《黄帝内经》中与此相爸的理论应 当受西汉前期盖天说的影响。

(2)浑天说。“夫变化之为用, 天垂象, 地成形, 七曜 纬虚, 五行丽地。地者, 所以载生成之形类也; 虚者, 所以列应天之精气也。形精之动, 犹根本之与枝叶也。 仰观其象, 虽远可知也。帝日：地之为下, 否乎? 岐伯 日：地为人之下, 太虚之中者也。帝日：凭乎?岐伯 日：大气举之也”（《素问·五运行大论》）。这就是 《黄帝内经》中运用浑天说的宇宙结构观构建相䏌理论 的。何谓浑天说? 浑天说认为全天恒星都布于一个“天 球”上,而日月五星则附丽于“天球”上运行, 这与现代天文 学的天球概念十分接近。这一学说最初认为, 地球不是 孤零零地悬在空中的, 而是浮在水上。后来又认为地球 浮在气中.因此有可能回旋浮动, 这是朴素的地动说之先 河。该宇宙结构观形成于先秦, 于西汉时期已趋成熟, 其观点详细地记载于东汉张衡《浑天仪图注》之中, 认 为宇宙“浑天如鸡子, 天体圆如弹丸, 地如鸡中黄, 孤 居于内, 天大而地小, 天表里有水, 天之包地, 犹壳之 疃黄。天地各乘气而立, 载水而浮”。该学说强调天体 没有一定形状, 亦非固体之物质造成, 日月星辰均飘浮 于太空之中, 乘气而行, 进退迟速, 各任其情。可见, 《黄帝内经》在其构建相兊理论时收到了这一有兊宇宙 结构观点的影响。

(3)宣夜说。《黄帝内经》的“太虚胗廓，肇基化元， 万物资始，五运终天，布气真灵，总统坤元，九星悬 
朗，七曜周旋，日阴日阳，日柔日刚，幽显既位，寒 暑弛张, 生生化化, 品物咸章”（《素问·天元纪大 论》), 以及“天至广不可度, 地至大不可量” (《素 问.六节藏象论》) 认识, 应当说是接受了西汉时期先 进的宣夜说，并且用以构建自己的理论体系。宣夜说是 我国历史上最有卓见的宇宙无限论思想, 最早出现于战 国时期，到汉代则已经有了明确表达。什么是宣夜说？ 这一观点认为,所谓“天”，并没有一个固体的“天穹”, 而只不过是无边无涯的气体，日月星辰就在气体中飘浮 游动。正如《晋书-天文志》所记载, “汉秘书郎郗萌记 先师相传云：天了无质，仰而瞻之，高远无极，眼贅精 绝, 故苍苍然也。譬之旁望远道之黄山而皆青, 俯察千 灱之深谷而窈黑，夫青非真色，而黑非有体也。日月众 星，自然浮生虚空之中，其行其止皆须气焉。是以七曜 或逝或住，或顺或逆，伏见无常，进退不同，由乎无所 根系, 故各异也。故辰极常居其所, 而北斗不与众星西 没也。摄提、填星皆东行, 日行一度, 月行十三度, 迟 疾任情, 其无所系著可知矣。若缀附天体, 不得尔也” 。由此可见,宣夜说认为,所谓“天”，并没有一个固体的 “天穹”, 而只不过是无边无涯的气体, 日月星辰就在气 体中飘浮游动。该观点是中国古代一种朴素的无限宇宙 观念。宣夜说起源很早，汉代郄萌（公元1世纪）只是 记下了先师所传的内容。此说认为天是没有形体的无限 空间，日月众星自然浮行无限高远的虚空之中，依赖气 的作用而运动。各天体虽然运动状态不同, 速度各异, 但都是漂浮在空中。可见《黄帝内经》相䏌理论的构建 只能是在这一学说成熟的过程之中或者之后。

\section{2.二十八宿。}

《黄帝内经》在构建相爸医学理论时运用了有爸二 十八宿的知识，如运用了 “天周二十八宿，而一面七 星，四七二十八星。房昂为纬，虚张为经。是故房至毕 为阳, 昂至心为阴。阳主昼, 阴主夜”解释人体营气卫 气昼夜循行规律 (《灵枢. 卫气行》)。再如为了运用 “丹天之气经于牛女戊分, 鞈天之气经于心尾己分, 苍 天之气经于危室柳鬼，素天之气经于六氏昂毕，玄天之 气经于张翼娄胃。所谓戊己分者, 奎壁角输, 则天地之 门户也。夫候之所始, 道之所生, 不可不通也” 阐述五 气经天化五运的理论（《素问·五运行大论》）。在 《灵枢》中引用二十八宿之名，已经达到完备阶段，与
西汉时期所言皆同。二十八宿是古人在天文学方面的重 大发展。二十八宿亦名二十八舍。指我国古代天文学家 把周天黄道(太阳和月亮所经天区)的恒星分成二十八个 星座。从历史文献可见，对二十八宿的宿数、星座及星 名的最后认定有一个发展的过程，早期文献如《尚书》

《诗经》及《夏小正》中, 提及星名较少。至秦、汉时 期之文献中，则逐步完善。《礼记·月令》中已有记载 但数目不全。战国末期的《吕氏春秋·有始览》的记载 较为完善。直至《淮南子·天文训》二十八宿有了准确 的名称和在天球中的排列顺序。1978年湖北省清县播 鼓敦战国早期會侯乙墓出土的漆箱盖上二十八宿星数相 同，惟用字取名方面有差异，说明二十八宿之数的最终 确定，似应在战国末至秦代，而名称的最终确定应当在 《淮南子.天文训》。从《内经》所用二十八宿的名称 以及排列顺序情况看，与此相䏌内容的形成不应当早于 这一时期。

\section{3.五星运行。}

五星指水、木、金、火、土五大行星，即东方岁星 (木星)，南方苂惑(火星)，中央镇星(一作填星。土 星)，西方太白(金星)，北方辰星(水星)。五星之名所见 甚早，在《尚书》《左传》等都勫有过记载，而记载详 备，且又与五行相合，与五季(春、夏、季夏、秋、冬) 相配者。《淮南子.天文》《史记·天官书》均有比较系 统的五行系列内容并将五方、五行、五帝、五佐、五 执、五神、五兽、五音、五日予以组合。

在《素问·金贵真言论》之五方系列组合中，即含五 星在内，与《淮南子》所列均同。《素问.气交变大 论》䏌于五运太过不及之论述，亦皆及于五星。又该篇 在论岁候之太过不及上应五星时，曾言及五星运行之逆 顺、留守等情况。如云：“以道留久，逆守而小，是谓 省下。以道而去，去而速，来曲而过之，是谓省遗过 也。久留而环，或离或附，是谓议灾与其德也。应近则 小，应远则大......岁运太过，则运星北越，运气相得， 则各行以道。故岁运太过, 畏星失色而兼其母, 不及, 则色争其所不胜。省者篗㫿，莫知其妙，闵闵之当，孰 者为良。妄行无徵, 示畏侯王。”说明《素问》中有爸 五星运行之论述，不仅与《淮南子》《史记》等同，而 且其以五星反应神权之占星术思想，亦颇相近。

\section{4. 日行一度, 月行十三度。}


日月运行, 亦名日䠖 (chán运行) 月离。古人早已 注意到日月的运行, 并根据其运行的周期, 作为制定历 法的依据。爸于太阳运行一度, 月球运行13. $7 / 19$ 度 的认识《淮南子.天文训》已有记载, 认为“月日行十三 度七十六分度之二十六”, 《素问. 六节藏象论》所言的 “日行一度, 月行十三度有奇焉。故大小月三百六十五 日而成岁，积气余而盈国矣”与此一致。王冰注：“日行 迟, 故昼夜行天之一度, 而三百六十五日一周天, 而犹 有度之奇分矣。月行速, 故昼夜行天之十三度余, 而二 十九日一周天也, 言有奇者, 谓十三度外, 复行十九分 度之七, 故云月行十三度而有奇也。”可见此说亦源于 西汉。

\section{5.九宫八风太乙游。}

九宫之名最早见于《易纬·乾丵度》卷下, 虽有多 义, 但主要是指术数家所指的九个方位。八风之名, 久 已有之, 然称谓不一。如《吕氏春秋·有始》与《淮南 子·坠形训》中的提法就不一致。然《灵枢·九宫八风》 所言的九宫, 则与后者之义相同, 乃以四正四维之八 方，与八卦方位结合，加之中央为九宫。故此太一游 说, 疑当出自两汉时方术家或占星术者之手。

\section{6. 正月建寅。}

正月建寅, 与历法相关。所谓“建” 者, 亦即月建, 指历法中运用十二地支分别标记一年十二个月的方法。 古代以北斗七星斗柄的运转作为定季节的标准, 将十二 地支与十二月相配, 用以纪月。把每年的岁首正月, 定 位在斗纲（即北斗七星的 $1 、 5 、 7$ 星）所指的十二辰中 寅的时位。《淮南子》的作者, 生活在汉武帝时期, 书 中有䏌 “正月建寅” 的历记方法应当与汉武帝于太初元年 颂行的《太初历》是一致的。《太初历》规定一年等于 365.2502 日，一月等于 29.53086 日; 将原来以十月为 岁首己改为以正月为岁首; 开始采用有利于农时的二十四 节气; 以没有中气的月份为国月, 调整了太阳周天与阴 历纪月不相合的矛盾。这是我国历法上一个划时代的进 步。《太初历》还根据天象实测和多年来史官的记录, 得出一百三十五个月的日食周期。《太初历》不仅是我 国第一部比较完整的历法, 也是当时世界上最先进的历 法, 1972年, 在山东临沂银雀山二号汉墓中, 出土了 汉武帝元光元年(公元前134年)的历谱竹简, 为秦及汉 初采用颛项历提供了确切的证据。至汉武帝太初元年
(公元前104年)颁行的《太初历》仍用四分法, 改正月 为建寅。在《素问·脉解》篇中就有“正月太阳寅” “阳明 者午也，五月盛阳之阴也”“太阴子也，十一月万物气皆 藏于中”“厥阴者辰也，三月阳中之阴”。《灵枢·阴阳系 日月》将十二个月与十二辰全部标明, 即寅者正月, 卯 者二月，辰者三月，已者四月，午者五月，未者六月， 申者七月，西者八月，戌者九月，亥者十月，子者十一 月, 丑者十二月。从正月建寅而论, 距离夏历相去古已 远, 很难影响到《内经》的理论建构, 故与西汉武帝时 颁行《太初历》的历史背景有很大爸系。大凡《黄帝内 经》中涉及到历法知识的内容, 无论是正月建寅, 还是 置闰, 还是 24 节气等等, 无不受到这一时期有爸历法 知识的影响。

\section{7.二十四气、七十二候。}

二十四气与七十二候是古代历法的主要内容和特 征。爸于二十四气之名，在今《素问》《灵枢》中，已 言及立春、立夏、立秋、立冬、春分、秋分、夏至、冬 至八个主要节气。爷于七十二候之事, 虽然没有提及具 体名称，但《素问》中已言及“五日为一候”之说，按一 年计之, 说明七十二候之数已经确立。《素问·六节藏 象论》云: “五日谓之候, 三候谓之气, 六气谓之时, 四时谓之岁” “七十二候”及“二十四气”的问题, 此乃我 国古历法重要特征之一。䏌于记载一年中“候”“气”之文 献亦较早, 然其最终确立之名称及数目, 则较晚, 有些 学者以为, 在秦汉之时。《吕氏春秋・十二月纪》始有 孟春、仲春、孟夏、仲夏、孟秋、仲秋、孟冬、仲冬八 个月，各安插立春、日夜分、立夏、日长至、立秋、日 夜分、立冬、日短至八节。《礼记·月令》和《淮南子. 时则训》都是十二月纪的合抄本，这说明了前汉初年， 还没有确定。24节气名称, 但在《淮南子. 天文训》中 不但有 24 节气的名称, 而且其顺序、推算方法都很详 细，现今通用的 24 节气名称及次序完全与之相同。一 年分二十四气，大概是前汉初年以后，《淮南子》成书 (公元前139年)以前。在《黄帝内经》的多篇都言及其 中的四立、二分、二至八节名称与《淮南子》相同。可 以确认《素问.六节藏象论》的有爸内容应是在 24 节气 与七十二候之名称及时序完全确立之后提出来的, 应与 该时期有䏌文献有称引知系 [3]。 


\section{四、西汉主要文献对《黄帝内经 》成书的影响}

\section{$(\rightarrow$ 《淮南子》与《黄帝内经》的理论建构}

《淮南子》的出现全面影响了《黄帝内经》理论的 建构和成书。其中的“争收并蓄”治经理念成为《黄帝内 经》理论建构的重要思路。秉承先秦道家宇宙观的本体 论, 认为宇宙万物同源于气, 气是宇宙万物生成本原, 道是宇宙万物运动变化的共同规律，在此大前提之下， 也以“道”以“气”论述人类生命活动。在气、阴阳、五行 哲学思想之下解释相爸现象, 其中包括人类生命活动, 这些内容都对《黄帝内经》的理论具有高度的一致性。 其中有爸养生、病证、治疗, 以及药物的内容, 不但反 映了西汉早期医药学成就, 也说明这一时期的医学成就 对包括《黄帝内经》在内的医学理论构建具有十分重要 的奠基作用 $[4]$ 。

\section{$(二$ 《春秋繁露》与《黄帝内经》理论的构建}

董仲舒所著的《春秋繁露》深受汉武帝的重视和推 崇，82篇内容以《春秋公羊传》资料为基础，凸显了 他的政治主张和学术立场。他用当时人们对人类自身形 体大致构造、某些生理机能、脏腑形体爸系、形神爸系 的医学认识，言思想、言文化、言治国、言治事、言治 人等等，其中宣扬了“天人合一”“天人感应”观点，运用 精气、阴阳、五行等世界观和方法论阐释治国方略的、 社会的、伦理道德的, 以及生命科学的等相爸道理, 除 有专章讲述养生之外相爸内容还散见于别章, 较全面地 勾勒出这一时期人们对养生的认识。作为影响汉武帝期 朝野思想的《春秋繁露》, 也就很自然地体现了这一时 期的医学成就，也可以从中窥视到此后成书《黄帝内 经》理论构建的相䏌背景。可以从中窥视到此后成书 《黄帝内经》理论构建的相爸背景 [5]。

\section{$\Leftrightarrow$ 《史记》与《黄帝内经》}

《黄帝内经》成书虽然晚于《史记》, 但是《史记. 扁鹊仓公列传》仅仅 29 个医学案例约 1.1 万字的内容, 就与《黄帝内经》在征引医学文献名谓、行文格式、问 对体例、医学术语、精气一阴阳一五行的哲学思想、疾 病传变规律、“治未病”理念、“病人为治病之本”的观
念、用“整体观念”阐述医学知识、10岁的年龄段划 分、重视“胃气”在疾病预后变化中的意义、“杂合以治” 的治病理念等 12 个方面的具有高度的一致性。根据其 中所传载的医学信息, 提示司马迁及其此后时代的医学 成就已经为《黄帝内经》理论的构建和成书准备了充足 的文化基础、哲学基础、思维基础、方法学基础，尤其 是构建医学理论时所必须的临床实践基础。只要认真地 研读其中的内容后就有一种可以从中找到《黄帝内经》 的影子之感，紧随其后的几十年成书也成为顺理成章的 事情了 [6]。

\section{五、西汉医药成就对《黄帝内经 》成书的影响}

先秦时期, 是我国科学文化比较昌盛的时期, 在医 学方面, 不仅有诸多名医著称于时, 就医学文献而言, 在当时定有诸多文字材料, 而且一直流传于汉代, 为王 公贵族所收藏, 有的为医家所得, 则视为禁书。所谓 “禁书”者, 禁秘之书也。如《史记·扁鹊仓公列传》就 记载公乘阳庆传授给淳于意的医书有“黄帝、扁鹊之 《脉书》 《五色》”以及《上（经）》《下经》 《五色 诊》 《奇咳术》 《揆度》 《阴阳》 《外变》 《药论》 《石神》《接阴阳》等12种（《史记·扁鹊仓公列 传》), 高后八年, 淳于意已七十余岁, 故其生当在战 国末期，此记其“禁方书”为“古先道遗传”，必为先秦旧 籍无疑。另外, 长沙马王堆出土的《阴阳十一脉炎经》 及《足臂十一脉尒经》等古医书, 《马王堆医书考释》 认为是“秦汉以前的医学原著”。此后江陵张家山出土之 《脉书》, 其十一脉与马王堆《阴阳十一脉炎经》内容 显系同一祖本，且原有题名为《脉书》。而淳于意得到 的12种医书中就与《黄帝内经》征引的30部文献名相 同或者相近。这8部相一致的征引文献分别占两部书征 引文献的 $66.67 \%$ 和 $27.6 \%$ [5]。说明《黄帝内经》在 西汉时期成书时引用了这些先秦时期的医学文献并与之 一脉相承。在《内经》的经络理论中不但沿用了《阴阳 十一脉尒经》及《足臂十一脉尒经》两部文献有䏌五脏 六腑所属 11 条经脉的名称及其基本循行路径, 而且在 《灵枢·寒热病》中有“臂太阴” “臂阳明”, 在《素问》 的多篇中将“太阳经”称为“巨阳经”等都与两本出土的帛 
书提法相同 ; 《灵枢·邪客》所论的“少阴独无输”就是 讨论只有 11 条正经的道理, 显然此处论述就与出土的 两部有爸经脉的文献有直接的䏌系; 《灵枢·五色》所 用的篇名以及所论的望色诊法内容无疑与其参阅所引书 目中的《五色》文献有爸; 《灵枢·胀论》在论述胀病 内容之后于篇中明确指出所引内容出自古文献的《胀 论》。另外, 《黄帝内经》中虽然只记载了13个方剂 20 多味药物, 但却讲述了十分丰富的用药规律以及组 方法度 [7], 如对《黄帝内经》理论构建和成书影响较 大的《淮南子》中同样也载有8首方剂 20 多味药物, 这 不能不说是与西汉时期及其以前临床中药学的成就有 爸。

总之, 《黄帝内经》的成书不是偶然事件, 是我国 先民在长期与疾病作斗争的过程中积累的大量实践经验 的结晶, 也只有在这个中国第一个政治稳定, 国民经济 富庶，思想文化繁荣的西汉王朝的大背景之下发生。

\section{【参考文献】}

1, 张登本.先秦诸子百家学术思想对《内经》理论构 建的影响 [J],陕西中医学院学报, 2002 (3) : $1 \sim 6$.

2, 张登本.内经的思考 $[\mathrm{M}]$. 第一版, 北京: 中国中 医药出版社, 2006:110 117.

3 , 达美君, 张宁、《黄帝内经》成书年代述考 $[\mathrm{J}]$, 上 海中医药杂志，1995，（11）:3 6.

4 , 张登本, 《淮南子》与《黄帝内经》的理论建构 [J], 陕西中医学院学报, 2012, 28 ( 4) :1 8.

5 , 张登本, 《春秋繁露》与《黄帝内经》理论的构 建 $[\mathrm{J}]$, 山西中医学院学报, 2012 , 5) :1 10.

$6, \quad$ 张登本, 《史记》与《黄帝内经》理论的构建 [J], 医学争鸣, 2013, (2) : 5 8.

7 , 张登本. 论《黄帝内经》的用药规律 $[J]$, 陕西中医 函授，1993，（2）1 6. 